Proceeding ICOGISS 2019

Page 247-257. ISBN: 978-602-6 988-75-1

Web Jurnal Online: jurnal.unmuhjember.ac.id By: Norodin D.Salam,Ph.D

Role of Academe in Preventing and Countering Violent Extremism in the Pursuit of Peace and Community Resilience in Central Mindanao, Philippines

\title{
ROLE OF ACADEME IN PREVENTING AND COUNTERING VIOLENT EXTREMISM IN THE PURSUIT OF PEACE AND COMMUNITY RESILIENCE IN CENTRAL MINDANAO, PHILIPPINES
}

\section{Norodin D. Salam}

Cotabato City State Polytechnic College

Email:norissalam@yahoo.com.ph

\begin{abstract}
This study seeks to identify the extent of the awareness delivered by government agency about war against illegal drugs, preventing and countering violent extremism in the pursuit of peace and development in Central Mindanao. Pre-test and post-test as well as analysis of variance was used to analyze the extent of the awareness. The result shows that the awareness of the participants increase after each government agencies delivered lecture.
\end{abstract}

Keywords: Violent extremism, government agency, higher education, Cotabato City 


\section{INTRODUCTION}

Violent extremism has become an area of interest to government and policy makers throughout the world. In the last decade, the field of international relations has undergone a revolution in conflict studies. Where earlier approaches attempted to identify the attributes of individuals, states, and systems that produced conflict, the "rationalist approach to war" now explains violence as the product of private information with incentives to misrepresent, problems of credible commitment, and issue indivisibilities (Fearon, 1995).

The need for a formal conduct of study has been undertaken because the issue is global threat that affects the hearts and minds of the people. Our country Philippines has already experience of this problem (e.g Marawi Siege) as one of the high value targets in Asia, therefore the idea of coming up with concerted efforts for different line agencies so as to strengthen the initiatives of combating violent extremism and other problems in the country. Therefore, each sector would think of their means to contribute to the eradication of the program. CCSPC as academic institution had found its role in countering violent extremism which became a stepping stone of other institution to do the same.

The result of the study may benefit the local government units and academic institutions to plan their activities related to the problem. The result of this project is available for all sectors as exhibit and showcase upon proper coordination and protocol to the head of institution CCSPC.

Rigorous empirical research that would allow conclusive statements on violent extremism is rare, so extremist violence tends to be explained through untested theories. Political interests may also inform an explanation or definition.

Causes of violent extremism are often divided into 'push' and 'pull' factors. This overlooks links between them, however, and can lead to over generalization. 'Individual' and 'community' factors are more useful categories though still interconnected.

Factors at the individual level include:

Personal relationships: These are important in spreading or reinforcing extremist ideas, and a radicalising peer group can provide a sense of belonging.

Beliefs, values and convictions: Extremist beliefs can be religious, spiritual, moral, or political and tend to express the conviction that a group, a way of life, or a political system needs to be challenged or destroyed. The perception of being denied recognition at a collective and personal level is considered critical.

Manipulation: Manipulation by extremist groups happens in a complex interplay of identity formation and other enabling factors. Whether there is a causal relationship between access to information (including to social media) and extremism is under-researched. This also challenges counter-approaches that use media strategies.

Trauma and humiliation: How emotions of humiliation and betrayal result in the reproduction of violence is a topic in urgent need of research (Mroz, 2009).

\section{LITERATURE REVIEW}

Most studies and academic papers on the concept of radicalization and violent extremism are published in Western journals mostly written by Western authors from Western universities (Schmid, 2013), hence, not much has yet been written about the concept of radicalization and violent extremism outside the Western setting, such as the Philippines, apart from several newspaper articles (Geronimo, 2016; Ressa,2017) and only a handful of other (opinion) papers have investigated on radicalization and violent extremism in the Philippines so far (ICG, 2016; IPAC, 2017; Lingga, 2014; Rasul, 2015; Timberman, 2013).Moreover, there is also inconsistency between literature analyzing radicalization processes in peaceful (mostly Western) versus conflict settings. It will, therefore, be crucial to mirror and balance these Western views and Western contexts by detailed findings from 
other parts of the world, including those from the Philippines and, specially, in conflictaffected Muslim Mindanao.

\section{Understanding Radicalization and Violent Extremism}

There is no universal agreement on the definition of terrorism. Various legal systems and Government agencies use different definitions. Moreover, governments have been reluctant to formulate an agreed upon and legally binding definition and the difficulties arise from the fact that the term is politically and emotionally charged (Wikipedia). In the review of Literature, it can be understood undoubtedly that universally accepted definitions of "radicalization" and "violent extremism" not do yet exist (Christmann, 2012; Schmid , 2015; Rahimullah etal, 2013; RESOLVE, 2016; Veldhuis \& Staun,2009).

\section{Academic Definitions}

There are numerous definitions of radicalization, and the term is highly can tested in academic as well as policy discourses. It is used to denote complex phenomenon/phenomena and means different things is different people (Schmid, 2004), while its meaning can vary with place and time (Neuman, 2013). According to Schmid (2011:217), radicalization studies "approach the field of extremism and terrorism by focusing on the processes through which individuals become socialized into engaging in political violence without moral restraints". The European Commission's Export Group on Violent Radicalization (2008: 5) denotes radicalism as follows: "radicalism as advocacy of, and commitment to, sweeping change and restructuring of political and social institutions has historically been associated with left and right-wing political parties - at times even with centrist and liberal ideologies and involves the wish to do away with traditional and procedural restrictions which support the status quo. As an ideology, radicalism challenges the legitimacy of established norms and policies, but it does not in itself, lead to violence." According to Bartlett, Birdwell and King (2010:10), radicalization that does not lead to violence - non-violent radicalization - refers to "the process by which individuals come to hold radical views in relation to the status quo but do not undertake, or directly aid or abet terrorist activity referred to as "radicals'. Conversely, violent radicalization is 'a process by which individuals come to undertake terrorist activity, or directly aid or abet terrorism". Della Port and LaFree (2012) argue that "action (behavior) and attitudes (aims and perceptions) are linked but must not be understood as necessarily depending on or even corresponding to each other. "instead, social movement research has found that "becoming involved in violent groups and engaging in acts of violence does not always presume adherence to radical aims and frames of reference, but can be motivated by, for example, personal relationships and loyalty to a group" (Ibid). Others, on the contrary, reject this ambiguity and argue that a holistic understanding of radicalization cannot be achieved through separating political beliefs from political action (Neumann,2013: 873). These positions have given rise to different theoretical and policy approaches.

\section{Policy and law enforcement definitions}

The Preventive Strategy of the UK Government provides the following definitions of radicalization, extremism and violent extremism: (HM Government, 2011; House of Commons Home Affairs Committee, 2012):

- Radicalization is defined as "the process by which a person comes to support terrorism and forms of extremism leading to terrorism."

- Extremism is defined as "vocal or active opposition to fundamental British Values, including democracy, the rule of law, individual liberty and mutual respect and tolerance of different faiths and beliefs."

- "Violent extremism" is considered to mean the endorsement of violence to achieve extreme ends.

According to Danish Security and Intelligence Service (PET), radicalization is "a process in which a person is increasingly accepting the use of undemocratic or violent means, 
including terrorism, in an attempt to achieve a specific political and ideological goals' (Kühle \& Lindekilde, 2010:24).

The General Intelligence and Security Service (AIVD) of the Netherlands considers radicalization to be 'the (active) pursuit of and/or support to far-reaching changes in society which may constitute a danger to (the continued existence of) the democratic legal order (aim), which may involve the use of undemocratic methods (means) that may harm the functioning of the democratic legal order (effect)' (General Intelligence and Security Service, 2004: 13).

The Norwegian government in its Action Plan against Radicalization and Violent Extremism (Norwegian Ministry of Justice and Public Security, 2014: 7) provide separate definitions for radicalization and violent extremism. Radicalization is understood as "a process whereby a person increasingly accepts the use of violence to achieve political, ideological or religious goals. A process of radicalization that results in violent extremism is characterized by: i) a cognitive development toward a steadily more unilateral perception of reality, where there is no room for alternative perspectives; ii) thereafter, a further development where the perception of reality is experienced so acutely and seriously that violent actions appear necessary and just." The Action Plan defines violent extremism as "activities of persons and groups that are willing to use violence in order to achieve their political, ideological or religious goals".

According to the Swedish Security Service (Säpo, 2009), radicalization can be both 'a process that leads to ideology or religious activism to introduce radical change to society' and a "process that leads to an individual or group using, promoting or advocating violence for political aims."

The definition of the US Department of Homeland Security (DHS) is: 'The process of adopting an extremist belief system, including the willingness to use, support, or facilitate violence, as a method to effect social change.' In the United States of America, for example, Terrorism is defined in Title 22 chapter 38 U.S. Code S $2656 \mathrm{f}$ as "premeditated, politically motivated violence perpetrated against noncombatant targets by subnational groups or clandestine agents."

In the Philippines, Republic Act no. 9372 (Human Security Act of 2007) defines a "terrorist" thus, any person who commits an act punishable under any of the following provision of the Revised Panel Code: a. Article 122 (Piracy in General and Mutiny in the High Seas or in the Philippine Waters); b. Article 134 (Rebellion nor insurrection); c. Article 134-a (coup d'état), including acts committed by private persons; d. Article 248 (Murder); e. Article 267 (Kidnapping and Serious Illegal Detention); and f. Article 324 (Crimes Involving Destruction). Thereby propagating and producing a condition of widespread and extraordinary distress and frighten the populace, in order to pressure the government to give in to an unlawful claim shall be guilty of the crime of terrorism and shall suffer the penalty of forty (40) years of imprisonment, without the benefit of parole as provided for under Act no. 4103, otherwise as the Indeterminate Sentence Law, as amended.

\section{The Global and Local Context on Terrorism affecting the Youth}

The world is currently experiencing a wave of terrorism (24) that is religiously motivated in its origins. The September 11, 2001 attacks in New York City and Washington D.C., the 7July 2005 London underground attacks as well as the various bombings in Indonesia since the first Bali attacks in October 2002 were all perpetrated by religiously motivated terrorist networks. As the authors of as well-known New York Police Department (NYPD) study religious-motivated radicalization in the West suggest, terrorism is the ultimate consequence of the radicalization process. Against this wider backdrop, it has been clear for years that youth are prone to violent radicalization processes that lead to such religiously motivated terrorist acts. In a mental or cognitive sense, when youth perceive that their group is under attack, especially physical attack, a drastic identity simplification dynamics kicks in. when the young people of a particular religious community perceive that they are being attacked by a powerful enemy- "Them" all these various social identities get 
thrown out the window in favor of one single dimension of collective identification in normal situation, as the Nobel laureate Amartya Sen memorably puts it: "The same person can, for example, be a British citizen, of Malaysian origin, with Chinese racial characteristics, a stockbroker, a non-vegetarian, an asthmatic, a linguist, a bodybuilder, a poet, an opponent of abortion, a bird-watcher, an astrologer, and one who believes that God created Darwin to test the gullible."

Youth are commonly defined the United Nation as individuals between the ages of 15 and 24 years representing a significant portion of the world's population. There are 1.5 billion people live in fragile or conflict affected countries of which $40 \%$ are young people (Global Youth Forum, 2015). It .s therefore necessary to understand the voices of the youth and to take youth issues seriously. As youth go through the transition stage from childhood to adulthood, they face many new psycho-social experiences as well as emotional turbulence, they are often confused about their identity, and they long for a sense of belonging and acceptance. Many feels very unsure and undecided about their future. At the other end of the spectrum, the youth have a tremendous potential for growth. They are often highly motivated in developing and seeking opportunities to explore new ideas and relationships, within the context of the society as a whole. Therefore, positive development is not only determined by the youth themselves but also by the environment. The approach to youth development should also encompass opportunities and experiences for young people to contribute in a meaningful way to their communities and to believe that their contributions are respected and valued.

Inevitably, a distributing and intensifying scene that a new, younger face of battle engages children as soldiers worldwide as the youths are starting to play significant role in this aspects as the terrorists have organized and strategically radicalize and recruit young people into committing acts of violence to carry their shameful acts in the name of God and perverse ideologies. About 20 percent of all suicide bombers are young are youths between 15 to 18 years old. Sadly, many youths, irrespective of race, religion, educational background or economic status have fallen prey into this game. Al-Qaeda used "new generation of Mujahidin" such as children and young people when conducting suicide attacks in Iraq, Afghanistan and Pakistan which increased the lethality of violence. As Islamic State (IS) has become very good at targeting young Muslims to come to Iraq and Syria and join foreign fighters in a struggle to build a caliphate, international terror group preys on youth vulnerabilities by encouraging them to pick up a weapon and carry out an attack.

One study revealed the many factors that pull young people to terrorist groups which can be ideational and material, that are mutually reinforcing. These pull factors are belt utilized with an effective recruitment strategy by a terrorist group to increase its membership and to keep the organization alive. One study has shown that the major pull factor that draws young person towards terrorist acts is ideology (Ginges, 1997). Ideology is deemed to be the main ideational pull mechanism "that makes possible the translation of discontent into specific political goals" of young individuals being lured to join terrorist groups. It is speculated that ideologies are "important organizers of experience and act as normal codes and motivations for actions" of young recruits. it is further argued that in the assessment of the perceived benefits of, and motivations for, terrorist acts of the youth, deeply understanding the virulent ideology of terrorist groups is essential. Ideology meaning to the emptiness felt by young people and defines their "reasons for existence". The profile of youths joining terrorist organizations through ideological motivations is that of mostly students, young professionals and learned individuals recruited from schools, universities and working places. Ideology is a pull factor in the radicalization of a small but significant minority of young persons dissatisfied with the society in which they find themselves (European Commission's Experts Group on Violent Radicalization, 2008). While ideology is indeed a pull factor in terrorism, there are young recruits who are induced to join terrorist groups not because of ideology but largely due to material considerations. Young person succumbing to this lure are mostly out-of-school youth in depressed areas or communities where poverty is pervasive, and the rate of illiteracy is high. These types of young persons 
are induced to join terrorist groups and commit acts of terrorism through the temptation of money, arms, and material needs of their families and loved ones. Terrorist groups buy the loyalties of their young recruits through tangible inducements in the form of money, perks, arms and other concrete benefits. These young members are made to work as combatants, bombers lookouts, and mules or to be simply errant persons (Homeland Security Institute, 2009).

A prospect of violence is more likely when there are limited opportunities to breakout the cycle of poverty (perceived or real), injustice and hopelessness. Terrorists group take advantage to cast-off these conditions by proposing to the youths what they are missing and offering them a 'way out' of their situation through martyrdom. Such tricky strategy of victimizing on susceptible youths has permeated in communities where there is a real or perceived injustice. Against this background, it is perhaps clear why youths are easily influence as heroic to join such groups - a narrative that is actively constructed and spread by terrorist groups. Through a terrorist organization organization has an ideology and material resources with which to entire young people to join, a well-planned recruitment strategy, a terrorist group cannot efficiency or automatically pull the youth to its side.

The Institute for Policy Analysis of Conflict (IPAC) concludes in its 2016 report that even as ISIS declines in strength in the Middle East, it is more imperative than ever to understand the followers it has formed in Southeast Asian and how they network with each other. The once peaceful and tolerant region home to multicultural and religiously diverse society, the Southeast Asia (SEA) is currently challenged with a threat from a worrying evaluation in radicalization and violent extremism (VE). Experts view that the Islamic State (IS) intends to create a base somewhere in the SEA region such as the Philippines (Habulan, 2016; IPAC, 2016; Ressa, 2017; Banlaoi, 2016), a Catholic majority country and strongest US ally in Southeast Asia, which was feared to have become the second front of the war against terror after Afghanistan.

\section{The Youth Radicalization and VE in Mindanao}

Radicalization of the entire or the majority of the Muslim population in the Philippines is unlikely, however, the extremist groups like could increase in number and that new radical groups would emerge due to a number of factors that could cause further radicalization including frustration over delays in the peace process and a failure to resolve the Bangsamoro problem, the existing anti-Muslim bias, and the presence of radical foreign Muslim in the Philippines coming from the Middle East seeking safe haven (Lingga, 2014; IPAC, 2016). The Global Terrorism Database (GTD) World Map focusing on the Philippines display the cumulative concentration and intensity (combining fatalities and injuries) of terrorist attacks across 45 years of data with Mindanao arguably having the highest intensity and concentration of armed encounters occurred in Southeast Asia. So far prevailing scholarly literature on terrorism have already acknowledged several factors of terrorism (Sebok and Braithwaite, 2005), however, none of these, may be applied generally to all terrorist organization because the behaviors of terrorist groups vary from country to country (Center for Nonproliferation Studies, 2002). Some VE groups may have shared common practices that cut across national borders. But vigorous social science investigations indicate that behaviors of terrorist organizations differ in historical context, socio-cultural milieu, politico-economic setting, specific intentions, exact target, and even particular tactics (Davis and Cragin 2009; cordes, et. al., 1985). Thus contending with the pull of terrorist is better understood on a case-to-case basis.

The ASG is an excellent case to examine the processes by which young persons are lured to enter terrorist organizations. The ASG is listed as a Foreign Terrorist Organization (FTO) by the Unites States (US) and an active International Terrorist Organization (ITO) by the United Nations (UN). Because of its involvement in kidnap-for-ransom activities, Philippine law enforcement authorities regard the ASG as a mere bandit group (Banlaoi, 2006). 
Proceeding ICOGISS 2019

Page 247-257. ISBN: 978-602-6 988-75-1

Web Jurnal Online: jurnal.unmuhjember.ac.id By: Norodin D.Salam,Ph.D

Role of Academe in Preventing and Countering Violent Extremism in the Pursuit of Peace and Community Resilience in Central Mindanao, Philippines

\section{METHODS}

The method used was survey. Measures Pretests at the beginning of the program. Posttest measures the extent of the awareness of the participants regarding the delivered topics by respective government agencies. Pre-test and post-test as well as analysis of variance was used to analyze the extent of the awareness.

\section{RESULTS AND ANALYSIS}

\section{Profile of the Respondents}

Majority of the respondents 50 percent were faculty members from different colleges of Cotabato City State Polytechnic College. Twenty percent were office staff while utility staff has the least respondents. Figure 1 shows the distribution of the respondents.

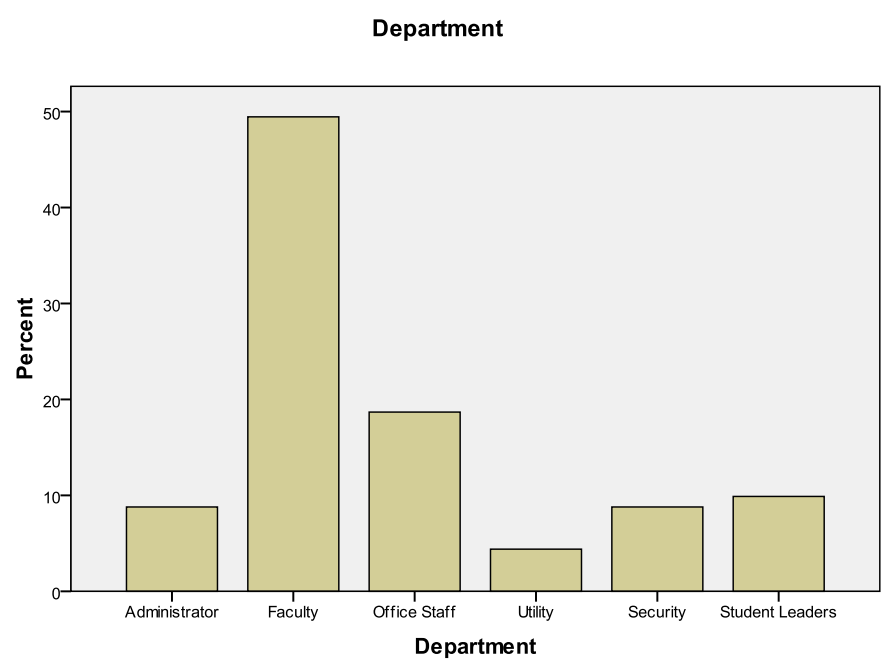

\section{PDEA ARMM}

Figure 1. Profile of the Respondents

The respondents rated neutral the extent of the awareness of the government agency (PDEA ARMM) during the pre-test with a grand mean of 3.44, while the post-test rated as aware with a grand mean of 4.15 . It means that the following were become clear to the participants after the lecture:

- The major programs of PDEA are supply reduction and demand reduction.

- PDEA is the agency of the government to conduct operation against drug users and pushers.

- PDEA ha overall programme steps from mapping to verification and Validation.

- PDEA would arrest anyone who has illegal drugs.

Table 1 shows the extent of the awareness of topics delivered by government agency (PDEA ARMM).

Table 1

The Extent of the Awareness of Topics Delivered by Government Agency (PDEA ARMM) $\mathrm{N}=151$

\begin{tabular}{|l|c|c|c|c|}
\hline PDEA ARMM & $\begin{array}{c}\text { Mean } \\
\text { Pre- } \\
\text { test }\end{array}$ & $\begin{array}{c}\text { Description } \\
\text { Pre-test }\end{array}$ & $\begin{array}{c}\text { Mean } \\
\text { Post-test }\end{array}$ & $\begin{array}{c}\text { Description } \\
\text { Post-test }\end{array}$ \\
\hline $\begin{array}{l}\text { The major programs of PDEA are } \\
\text { supply reduction and demand } \\
\text { reduction. }\end{array}$ & 3.37 & Neutral & 4.08 & Aware \\
\hline $\begin{array}{l}\text { PDEA is the agency of the } \\
\text { government to conduct operation } \\
\text { against drug users and pushers }\end{array}$ & 3.12 & Aware & 4.34 & Aware \\
\hline
\end{tabular}


Proceeding ICOGISS 2019

Page 247-257. ISBN: 978-602-6 988-75-1

Web Jurnal Online: jurnal.unmuhjember.ac.id By: Norodin D.Salam,Ph.D

Role of Academe in Preventing and Countering Violent Extremism in the Pursuit of Peace and Community Resilience in Central Mindanao, Philippines

\begin{tabular}{|l|c|c|c|c|}
\hline $\begin{array}{l}\text { PDEA ha overall programme steps } \\
\text { from mapping to verification and } \\
\text { Validation }\end{array}$ & 3.37 & Neutral & 4.05 & Aware \\
\hline $\begin{array}{l}\text { PDEA would arrest anyone who has } \\
\text { illegal drugs }\end{array}$ & 3.92 & Neutral & 4.16 & Aware \\
\hline GRAND-MEAN & $\mathbf{3 . 4 4}$ & Neutral & $\mathbf{4 . 1 5}$ & Aware \\
\hline
\end{tabular}

Range of Means

1.00-1.49 Not at All

1.50-2.49 Not Aware

2.50-3.49 Neutral

3.50-4.49 Aware

4.50-5.0 Highly Aware

\section{CCPO: Philippine National Police}

The respondents rated aware the extent of the awareness of the government agency (CCPO: Philippine National Police) during the pre-test with a grand mean of 3.56, while the posttest rated as aware with a grand mean of 3.90. It means that generally the participants were aware about the function and responsibilities of the PNP before and after the lecture. The following were become clear to the participants after the lecture:

- I am familiar to all security situations in Cotabato City.

- I know all the challenges of CCPO in maintaining peace and order in the City.

Table 2 shows the extent of the awareness of topics delivered by government agency (CCPO: Philippine National Police).

Table 2

The Extent of the Awareness of Topics Delivered By Government Agency (CCPO: Philippine National Police)

$\mathrm{N}=151$

\begin{tabular}{|l|c|c|c|c|}
\hline CCPO: Philippine National Police & $\begin{array}{c}\text { Mean } \\
\text { Pre- } \\
\text { test }\end{array}$ & $\begin{array}{c}\text { Description } \\
\text { Pre-test }\end{array}$ & $\begin{array}{c}\text { Mean } \\
\text { Post-test }\end{array}$ & $\begin{array}{c}\text { Description } \\
\text { Post-test }\end{array}$ \\
\hline $\begin{array}{l}\text { The CCPO is the local police unit to } \\
\text { maintain peace and order in Cotabato } \\
\text { City }\end{array}$ & 3.98 & Aware & 4.16 & Aware \\
\hline $\begin{array}{l}\text { I am familiar to all security situations } \\
\text { in Cotabato City. }\end{array}$ & 3.32 & Neutral & 3.49 & Aware \\
\hline $\begin{array}{l}\text { I know all the challenges of CCPO in } \\
\text { maintaining peace and order in the } \\
\text { City. }\end{array}$ & 3.44 & Neutral & 4.03 & Aware \\
\hline $\begin{array}{l}\text { PNP program on anti-violent } \\
\text { extremism. }\end{array}$ & 3.53 & Aware & 3.92 & Aware \\
\hline \multicolumn{1}{|c|}{ GRAND-MEAN } & $\mathbf{3 . 5 6}$ & Aware & $\mathbf{3 . 9 0}$ & Aware \\
\hline
\end{tabular}

Range of Means

$\begin{array}{ll}1.00-1.49 & \text { Not at All } \\ 1.50-2.49 & \text { Not Aware } \\ 2.50-3.49 & \text { Neutral } \\ 3.50-4.49 & \text { Aware } \\ 4.50-5.0 & \text { Highly Aware }\end{array}$


Proceeding ICOGISS 2019

Page 247-257. ISBN: 978-602-6 988-75-1

Web Jurnal Online: jurnal.unmuhjember.ac.id By: Norodin D.Salam,Ph.D

Role of Academe in Preventing and Countering Violent Extremism in the Pursuit of Peace and Community Resilience in Central Mindanao, Philippines

\section{Cotabato Public Safety Office}

The respondents rated neutral the extent of the awareness of the government agency (Cotabato Public Safety Office) during the pre-test with a grand mean of 3.29, while the post-test rated as aware with a grand mean of 4.03. It means that the following were become clear to the participants after the lecture:

- I know the mandate of office of Cotabato Public Safety.

- The Public Safety Office is maintaining safety and security through disaster preparedness program.

- CPSO is a special program of the City Mayor to address problems on radicalism.

Table 3 shows the extent of the awareness of topics delivered by government agency (Cotabato Public Safety Office).

Table 3

The Extent of the Awareness of Topics Delivered By Government Agency (Cotabato Public Safety Office)

$$
\mathrm{N}=151
$$

\begin{tabular}{|l|c|c|c|c|}
\hline Cotabato Public Safety Office & $\begin{array}{c}\text { Mean } \\
\text { Pre- } \\
\text { test }\end{array}$ & $\begin{array}{c}\text { Description } \\
\text { Pre-test }\end{array}$ & $\begin{array}{c}\text { Mean } \\
\text { Post-test }\end{array}$ & $\begin{array}{c}\text { Description } \\
\text { Post-test }\end{array}$ \\
\hline $\begin{array}{l}\text { I know the mandate of office of } \\
\text { Cotabato Public Safety. }\end{array}$ & 3.23 & Neutral & 4.03 & Aware \\
\hline $\begin{array}{l}\text { The Public Safety Office is } \\
\text { maintaining safety and security } \\
\text { through disaster preparedness } \\
\text { program. }\end{array}$ & 3.33 & Neutral & 4.00 & Aware \\
\hline $\begin{array}{l}\text { CPSO is a special program of the } \\
\text { City Mayor to address problems on } \\
\text { radicalism. }\end{array}$ & 3.32 & Neutral & 4.08 & Aware \\
\hline \multicolumn{1}{|c|}{ GRAND-MEAN } & $\mathbf{3 . 2 9}$ & Neutral & $\mathbf{4 . 0 3}$ & Aware \\
\hline
\end{tabular}

Range of Means

$\begin{array}{ll}1.00-1.49 & \text { Not at All } \\ 1.50-2.49 & \text { Not Aware } \\ 2.50-3.49 & \text { Neutral } \\ 3.50-4.49 & \text { Aware } \\ 4.50-5.0 & \text { Highly Aware }\end{array}$

\section{Commission on Human Rights}

The respondents rated neutral the extent of the awareness of the government agency (Commission on Human Rights) during the pre-test with a grand mean of 3.14, while the post-test rated as aware with a grand mean of 3.92. It means that the following were become clear to the participants after the lecture:

- The program and services of Commission on Human Rights.

- How to avail the program of the CHR?

- How to defend my rights as ordinary citizen under martial law?

- CHR office location is known and popular.

- The CHR is available anytime with proper procedures

Table 4 shows the extent of the awareness of topics delivered by government agency (Commission on Human Rights). 
Proceeding ICOGISS 2019

Page 247-257. ISBN: 978-602-6 988-75-1

Web Jurnal Online: jurnal.unmuhjember.ac.id By: Norodin D.Salam,Ph.D

Role of Academe in Preventing and Countering Violent Extremism in the Pursuit of Peace and Community Resilience in Central Mindanao, Philippines

The Extent of the Awareness of Topics Delivered By Government Agency (Commission on Human Rights)

$\mathrm{N}=151$

\begin{tabular}{|l|c|c|c|c|}
\hline Commission on Human Rights & $\begin{array}{c}\text { Mean } \\
\text { Pre- } \\
\text { test }\end{array}$ & $\begin{array}{c}\text { Description } \\
\text { Pre-test }\end{array}$ & $\begin{array}{c}\text { Mean } \\
\text { Post-test }\end{array}$ & $\begin{array}{c}\text { Description } \\
\text { Post-test }\end{array}$ \\
\hline $\begin{array}{l}\text { The program and services of } \\
\text { Commission on Human Rights }\end{array}$ & 3.30 & Neutral & 4.00 & Aware \\
\hline $\begin{array}{l}\text { How to avail the program of the } \\
\text { CHR? }\end{array}$ & 2.97 & Neutral & 3.84 & Aware \\
\hline $\begin{array}{l}\text { How to defend my rights as ordinary } \\
\text { citizen under martial law? }\end{array}$ & 3.27 & Neutral & 4.03 & Aware \\
\hline $\begin{array}{l}\text { CHR office location is known and } \\
\text { popular }\end{array}$ & 3.03 & Neutral & 3.84 & Aware \\
\hline $\begin{array}{l}\text { The CHR is available anytime with } \\
\text { proper procedures }\end{array}$ & 3.14 & Neutral & 3.92 & Aware \\
\hline \multicolumn{1}{|c|}{ GRAND-MEAN } & $\mathbf{3 . 1 4}$ & Neutral & $\mathbf{3 . 9 2}$ & Aware \\
\hline
\end{tabular}

Range of Means

$\begin{array}{ll}1.00-1.49 & \text { Not at All } \\ 1.50-2.49 & \text { Not Aware } \\ 2.50-3.49 & \text { Neutral } \\ 3.50-4.49 & \text { Aware } \\ 4.50-5.0 & \text { Highly Aware }\end{array}$

\section{Philippine Army}

The respondents rated neutral the extent of the awareness of the government agency (Philippine Army) during the pre-test with a grand mean of 3.49, while the post-test rated as aware with a grand mean of 4.04. It means that the following were become clear to the participants after the lecture:

- The programs and activities of the Philippine Army in addressing violent extremism.

- Best practices of Philippine Army in addressing radicalism (PCVE)

Table 5 shows the extent of the awareness of topics delivered by government agency (Philippine Army).

Table 5

The Extent of the Awareness of Topics Delivered By Government Agency (Philippine Army) $\mathrm{N}=151$

\begin{tabular}{|l|c|c|c|c|}
\hline Philippine Army & $\begin{array}{c}\text { Mean } \\
\text { Pre- } \\
\text { test }\end{array}$ & $\begin{array}{c}\text { Description } \\
\text { Pre-test }\end{array}$ & $\begin{array}{c}\text { Mean } \\
\text { Post-test }\end{array}$ & $\begin{array}{c}\text { Description } \\
\text { Post-test }\end{array}$ \\
\hline $\begin{array}{l}\text { The programs and activities of the } \\
\text { Philippine Army in addressing } \\
\text { violent extremism }\end{array}$ & 3.48 & Neutral & 3.97 & Aware \\
\hline $\begin{array}{l}\text { Best practices of Philippine Army in } \\
\text { addressing radicalism (PCVE) }\end{array}$ & 3.26 & Neutral & 3.97 & Aware \\
\hline $\begin{array}{l}\text { The Philippine Army as defender of } \\
\text { People against lawless elements. }\end{array}$ & 3.68 & Aware & 4.16 & Aware \\
\hline $\begin{array}{l}\text { Location of the Philippine Army } \\
\text { Headquarters }\end{array}$ & 3.57 & Aware & 4.05 & Aware \\
\hline \multicolumn{1}{|c|}{ GRAND-MEAN } & $\mathbf{3 . 4 9}$ & Neutral & $\mathbf{4 . 0 4}$ & Aware \\
\hline
\end{tabular}


Role of Academe in Preventing and Countering Violent Extremism in the Pursuit of Peace and Community Resilience in Central Mindanao, Philippines

Range of Means

$\begin{array}{ll}\text { 1.00-1.49 } & \text { Not at All } \\ 1.50-2.49 & \text { Not Aware } \\ 2.50-3.49 & \text { Neutral } \\ 3.50-4.49 & \text { Aware } \\ 4.50-5.0 & \text { Highly Aware }\end{array}$

\section{CONCLUSION}

Countering the threat posed by terrorism and violent extremism is a formidable challenge not only for law enforcement and other concerned government agencies but also for the wider society of citizens who are often times victims, casualties, and collateral damages of criminal, terrorist, insurgent and violent extremist activities. This paper describes some program that the academe may play a vital role to counter the violent extremism. The result is promising as it shows the great extent of the awareness of different government agencies function and responsibilities as well as those delivered topics. The Cotabato City State Polytechnic College as a State institution has a great role in combating violent extremism by means of awareness campaign and partnering with different line agency. It is a vital role of CCSPC especially it is located strategically at the heart of Central Mindanao. This program should be emulated by other agency so that the threat of violent extremism should decrease if not disappear.

\section{Recommendation}

Based from the findings of the study, the following recommendations were identified:

1. There is a need to institutionalize the program on Countering Violent Extremism, combating illegal drugs and corruption in all academic institutions in Central Mindanao.

2. Continuous capacity building for school administrators particularly the high ranking members of the academe for them to be fully grasp the implementation of the program.

3. The need for allocating funds intended for the countering violent extremism program to be used by the academic institutions.

4. Strengthen the partnership of law enforcers and academe in Violent Extremism, combating illegal drugs and corruption.

\section{References}

Fearon, James D. (1995). Rationalist Explanations for War. International Organization 49 (3):379-414.

Schmid, A. P. (2013). Radicalisation, de-radicalisation, counter-radicalisation: A conceptual discussion and literature review. ICCT Research Paper, 97, 22.

Mroz, J. (2009). Countering Violent Extremism. 